\title{
AUTOCOMUNICAÇÃO E CONTRAPODER: A ARQUITETURA DAS TIC COMO INSTRUMENTOS DE DIFUSÃO INFORMATIVA E O IMPACTO NA AGENDA POLÍTICA
}

Bruno Mello Correa de Barros*

RESUMO: Levando-se em conta os vértices de tecnologia, comunicação, desenvolvimento e informação que o presente trabalho se desenvolve, a fim de analisar os conceitos de autocomunicação e contrapoder na sociedade em rede e verificar se a arquitetura das TIC como instrumentos de difusão informativa possuem o condão de gerar um (im)possível impacto na agenda política. Para a consecução do objetivo proposto utiliza-se o método de abordagem indutivo, método de procedimento funcionalista, aliados à técnica de pesquisa baseada em fonte documental e pesquisa bibliográfica.

Palavras-Chave: Autocomunicação; Agenda Política; Contrapoder; Impacto; Informação.

\section{AUTOCOMMUNICATION AND CONTRAPODER: THE ARCHITECTURE OF ICT AS INFORMATION DISTRIBUTION INSTRUMENTS AND THE IMPACT ON THE POLITICAL AGENDA}

\begin{abstract}
Considering the vertices of technology, communication, development and information that the present work develops, in order to analyze the concepts of selfcommunication and counterpower in the network society and verify if the architecture of ICT as tools of information diffusion have the to have an (im)possible impact on the political agenda. In order to achieve the proposed objective, the method of inductive approach, method of functionalist procedure, allied to the research technique based on documentary source and bibliographic research, is used.
\end{abstract}

Keywords: Information; Impact; Counterpower; Political Agency; Self Communication.

\footnotetext{
* Docente do Curso de Direito da Faculdade Metodista de Santa Maria - FAMES. Mestre em Direito pelo PPGD da UFSM.
}

Rev. de Direito, Governança e Novas Tecnologias | e-ISSN: 2526-0049 | Porto Alegre | v. 4 | n. 2 | p. 22 - 43 | Jul/Dez. 2018 


\section{INTRODUÇÃO}

A sociedade revela-se através da composição de muitos matizes, definindo-se a partir de eixos sensíveis e de grande representatividade no meio social. Nessa perspectiva, os meios de comunicação constituem os vetores de transformação e consolidação, vez que possibilitam a dominação social, uma vez que corroboram potencializando as desigualdades sociais, políticas e culturais da sociedade, mas também configuram-se como formidáveis ferramentas propiciadoras das mudanças sociais, políticas e econômicas, uma vez que tendo o quadro sensorial formado por impulsos reflexivos críticos e bem informados, a partir de diferentes óticas e sob uma pluralidade de vozes e fontes é possível a transformação de qualquer âmbito.

Logo, tecnologia, desenvolvimento e comunicação correspondem aos vetores de transformação da sociedade contemporânea e dentro dessa perspectiva que se desenvolve o ensaio em tela. Sendo assim, o cenário da comunicação social brasileira proporciona cada vez mais a consolidação de um sistema que preconiza a sobreposição do capital hegemônico de grandes empresas e corporações, além de famílias e grupos religiosos, sobre o interesse da maioria.

A partir de tal quadro, limita-se a discussão, dissolvem-se as opiniões dissidentes, as vozes contrárias, silenciam-se os movimentos sociais, além de legitimar muitas vezes a desigualdade social, o preconceito e a luta de classes. E no mesmo aspecto, formaliza-se a alienação sobre questões inerentes a todo o sistema de direitos e garantias individuais próprios do Estado Democrático de Direito, visto que quando não há informação, logo não há conhecimento e, portanto, não há que se falar na luta pela reivindicação de direitos.

Desta feita, tendo como suporte as discussões acerca da comunicação e da informação e todos os aspectos relevantes desse meandro que se desenvolve uma discussão crítico-reflexiva acerca dos conceitos de autocomunicação e contrapoder, a fim de analisar se as TIC, especialmente a internet, podem atuar como instrumentos exponenciais de difusão informativa e observar o (im)possível impacto na agenda política. Deste modo, metodologicamente, para a implementação da presente pesquisa utiliza-se o método de abordagem indutivo, bem como o método de procedimento funcionalista, o qual se justifica pela necessidade de discussão acerca de tais balizas dentro de uma sociedade altamente célere, complexa e tecnológica. Por fim, consubstanciando-se tais métodos utiliza-se a técnica de pesquisa baseada em fonte documental e pesquisa bibliográfica.

Rev. de Direito, Governança e Novas Tecnologias | e-ISSN: 2526-0049 | Porto Alegre | v. 4 | n. 2 | p. 22 - 43 | Jul/Dez. 2018 


\section{A COMUNICAÇÃO E A PLURALIDADE DE VOZES NA PERSPECTIVA DA LIBERDADE DE EXPRESSÃO E DOS FLUXOS INFORMACIONAIS NO CIBERESPAÇO}

Assim como a prensa manual no século XIV e a fotografia no século XIX exerceram um impacto revolucionário no desenvolvimento das sociedades e culturas modernas, hoje situase no meio de uma revolução nas mídias e uma virada nas formas de produção, distribuição e comunicação mediadas por computador que deverá trazer consequências muito mais profundas do que as anteriores (SANTAELLA, 2003, p. 64). “[...] A Internet e sua relação com as mídias de massa são mais um episódio na história da transformação dos meios de comunicação causada pela complexa ação combinada de necessidades percebidas, pressões competitivas e políticas, e inovações tecnológicas" (RESENDE, 2002, p. 13).

A comunicação experimenta uma vertiginosa transformação, compondo novas táticas e dinâmicas, “[...] as novas condições técnicas de comunicação e informação têm o potencial de permitir a ampliação do conhecimento sobre o planeta, a sociedade e o homem, em sua realidade intrínseca (SALDANHA, 2013, p. 175), permitindo uma ampliação do alcance das relações sociais, visto a interconexão onde os indivíduos podem estabelecer contato estando em diferentes partes do globo. Contudo, é possível prescrever acerca da grande possibilidade de expor as manifestações de pensamentos e ideias por meio do fito virtual. "[...] A liberdade de expressão, com efeito, é parte essencial do micropoder surgido das mudanças sociais provocadas pela interatividade proporcionada pelas tecnologias digitais" (CREMADES, 2009, p. 200).

Desta feita, "[...] a rede global de redes de computadores, é um dos mais revolucionários meios tecnológicos, uma vez que permite a comunicação entre usuários de todo o mundo pela interconexão de redes" (CASTELLS, 2003, p. 13), corroborando assim como a perfectibilização de novas formas de organização e articulação em rede. Conforme destacado por Lévy (1999, p.33), a informática, desenvolvida nessa quadra da história, permite digitalizar as informações, armazená-las, tratá-las automaticamente, transportá-las e colocálas à disposição do usuário final, o que antes não acontecia. O evento mais considerável produzido pelo mundo cibernético pela vida da Internet, a ideia da livre circulação de informações, concorda plenamente com a livre movimentação dos fluxos de capitais, essência do neoliberalismo (SALDANHA, 2013, p. 182).

Em vista disso, fomenta-se a liberdade quando os meios de comunicação estão dispersos, descentralizados e facilmente disponíveis, como são as impressoras ou os 
microcomputadores. O controle central é mais provável quando os meios de comunicação estão concentrados, monopolizados e escassos, como nas grandes redes (JENKINS, 2008, p. 36), o que é o caso das comunicações no Brasil, as quais se compõem estritamente por empresas privadas e comerciais que estão submetidas aos imperativos de rentabilidade. $\mathrm{Na}$ era da globalização das relações, representada pela Internet, o tempo constitui-se em elemento de compreensão e até mesmo uma aniquilação do espaço, vez que importa em grande monta o comunicar - expressar-se - e informar - informar-se, a qualquer preço a um ritmo veloz (SALDANHA, 2013, p. 183).

A Internet permitiu a experimentação de um tipo de comunicação de âmbito mundial. Apresentou-se com um caráter atrativo, que levou a que os destinatários nela se empenhassem e adestrassem, e por outro lado ficassem dependentes deste modo de comunicação, segundo as concepções de Ascenção (2002, p. 69). Já para Saldanha (2013, p. 184) as avançadas tecnologias de produção e, em particular, as TIC muito bem serviram e servem de meios que favorecem enormemente a pressão em favor da aceleração dos processos de produção, das informações e das comunicações globais.

As modernas tecnologias proporcionam transformações em diversos âmbitos na sociedade, alterando o poder e as relações estabelecidas, uma vez que estas permitem um deslocamento geográfico das atividades tradicionais, permitindo, em muitos casos, a realização de uma prestação de serviços desde lugares remotos, com iguais garantias de confiabilidade e de qualidade. Para os países menos desenvolvidos, há o evidente risco de serem excluídos, a não ser que aceitem as condições laborais, salariais ou de assistência social inferiores aos estabelecidos para os trabalhadores dos países desenvolvidos. A globalização poderia converter-se, desta maneira, em uma nova leva de '[...] escravos tecnológicos', (SANCHESBRAVO, 2010, p. 26).

Para as empresas o rápido crescimento da globalização nos processos produtivos deverá impor a necessidade de uma reestruturação orgânica. Reestruturação que virá imposta fundamentalmente por dois fatores: a redução do tamanho das grandes empresas devido ao deslocamento de atividades e a própria natureza dos serviços ofertados, pois um mesmo sistema técnico pode ser condutor de uma ampla gama de produtos. A flexibilidade das novas tecnologias implica que as mesmas sejam incorporadas à organização social da empresa, de seus empregados e diretores, para conseguir, deste modo, uma conjunção competitiva de produtividade, qualidade e resultado (SANCHES-BRAVO, 2010, p. 27). 
Dentre as inovações e mudanças proporcionadas pela sociedade informacional as TIC poderão contribuir para reduzir as distâncias geográficas, contribuindo ao desenvolvimento e uma maior integração das regiões periféricas e menos desenvolvidas (SANCHES-BRAVO, 2010, p. 34), além disso, as novas comunidades virtuais de interação não devem substituir, em nenhum caso, mais sim complementar, a interação humana.

As novas TIC permitem às pessoas algumas possibilidades de interconexão e em tempo real, até agora desconhecidas. Assim, as conferências informáticas e a tribunas informáticas criam 'lugares" (novas ágoras) onde as pessoas de cultura e países diferentes entram em contato, desenvolvendo modos e formas de comunicação radicalmente aos tradicionais, conectados ao contato direto (SANCHES-BRAVO, 2010, p. 49).

É de assaz relevância destacar que as plúrimas benesses e possibilidades ofertadas pelas novas tecnologias não são afetas a todos os indivíduos sociais, visto que a amplitude de tecnologia e internet não são do alcance de todos. As sociedades democráticas ocidentais avaliam o caráter democrático e social levando em conta um elemento fundamental que é o direito de todos participarem. A explosão da informação que supõem as TIC parece, à primeira vista, favorecer a formação de opiniões e a transparência, mas os efeitos positivos para a democracia não parecem tão claros.

Deve-se considerar a máxima de que nem todos os cidadãos têm acesso às novas tecnologias, bem como de que a utilização das TIC não implica, em muitos casos, nem debate, nem confrontação de ideias, mas somente uma amálgama e sobreposição das ideias de cada um dos participantes, mas sem argumentos contraditórios ou críticos (SANCHES-BRAVO, 2010, p. 58-61).

Com esse propósito as tecnologias informacionais alargaram as possibilidades em se tratando de manifestação do pensamento e das ideias, vez que até então os modelos tradicionais de comunicação não possibilitavam de maneira ampla exasperar o conteúdo do pensamento individual através dos seus meios. A liberdade de expressão consiste no direito assegurado a cada um exprimir livremente as suas ideias e opiniões (SILVA, 2012, p. 10). Quer dizer, consiste no direito de alguém expor livremente uma opinião que possua sobre um determinado assunto, um juízo de valor, um pensamento, seja de natureza artística, científica, cultural, religiosa ou de acordo com a sua convicção íntima, sem compromisso qualquer com a veracidade ou com a imparcialidade (CAVALIERI, 2010, p. 114).

No que tange a esse direito, evidencia-se que a liberdade de expressão configura-se como um aspecto externo da liberdade de pensamento, quer dizer, como a possibilidade de 
exteriorização de um pensamento íntimo, de dizer aquilo que se crê verdadeiro (SILVA, 2012, p. 241-243). Diante do exposto, ele representa uma "[...] condição para a autodeterminação humana, pois pouco importa ao homem poder ter qualquer opinião, mas não poder expressá-la (SILVA, 2012, p. 241-243)".

Cabe salientar que as novas mídias reivindicam a posse da verdade da informação contra os desvios da comunicação de massa e faz isso a partir da utilização da liberdade de expressão, assim, insta destacar que esse direito não é um fim em si mesmo, mas um meio, a liberdade encontra sua gênese na concepção de que é um direito humano fundamental, ou seja, indissociável de um regime democrático. Conforme Dworkin $(2005$, p. 497) “[...] a liberdade de expressão e a democracia não estão vinculadas instrumentalmente, mas de maneira profunda, pois a dignidade que a liberdade de expressão protege é um componente essencial da democracia corretamente concebida".

Diante do exposto é imprescindível para o regime democrático a proteção da liberdade de expressão, a fim de preservar a composição de uma sociedade comprometida com esse regime jurídico, de modo que a Constituição Federal de 1988, no artigo $5^{\circ}$, IV, estabelece a liberdade de expressão como direito fundamental, conforme é possível prescrever: "[...] é livre a manifestação do pensamento, sendo vedado o anonimato" (BRASIL, 1988). Juntamente com os incisos VI, VIII e IX, todos do citado artigo $5^{\circ}$ da $\mathrm{CF}$, pode-se afirmar que formam o arcabouço jurídico-constitucional brasileiro de garantia do direito de liberdade de expressão e de liberdade de pensamento (SALDANHA, 2013, p. 186).

Todavia, a amplitude dessa liberdade tão largamente exposta na Carta da República é fortemente atacada frente a crescente oligopolização das comunicações, ainda mais que "a tecnologia de mídia dominante em qualquer época é uma força poderosa na modelagem da estrutura social, ao impor um regime mental específico, que permite às pessoas processarem a informação codificada na tecnologia" (MCLUHAN, 1964), sendo assim, como acredita Saldanha (2013, p. 189) “[...] uma concentração como esta obstaculiza o exercício da liberdade de expressão pelos cidadãos, a qual se completa no direito à informação livre e plural, constituindo um valor indissociável da ideia de democracia”.

A concentração de meios de comunicação não só limita o sujeito de expor uma determinada opinião, mas impede a pluralidade de fontes e a diversidade de conteúdos a que este está sujeito, restringindo seu direito à informação, e assim acaba por interferir direta e indiretamente em sua liberdade de expressão (SALDANHA, 2013, p. 189), deste modo, no 
mesmo aspecto, Souza (2005, p. 13) aponta que "[...] o termômetro que mede a democracia numa sociedade é o mesmo que mede a participação dos cidadãos na comunicação".

A partir de tal quadro é inerente a proteção deste direito basilar ao regime vigente, conforme aponta Tavares (2002, p. 409) “[...] este direito decorre do (próprio) princípio democrático, que consagra a tutela a coexistência da pluralidade de ideias e opiniões". No mesmo viés que ingressam as novas tecnologias informacionais que tem em sua base a Internet, como difusores de conhecimento, informação e, sobretudo, da expressão dos usuários, conforme coloca (DIZARD JR., 2000, p. 25):

A liberdade de expressão, ademais, antes do advento da redemocratização do Brasil e, consequentemente, da Constituição Federal de 1988 - que se operou como uma Carta de Direitos expressamente cidadã - era regulada pela Lei 5250, de 9 de fevereiro de 1967, concebida como Lei de Imprensa, editada, portanto, sob os auspícios da Ditadura Militar, ou seja, em total desacordo com princípios e garantias fundamentais, desrespeitando prerrogativas dos cidadãos. Essa legislação regulava a manifestação do pensamento e de informação de acordo com a ideologia empregada na época, quer dizer, a partir do ditame do regime militar autoritário operante no país, impondo assim ferrenhos limites à imprensa e a livre manifestação de pensamento.

Contudo, com o retorno à Democracia e a subserviência à Constituição Federal de 1988 e também de acordo com as mudanças ideológicas postas na contemporaneidade à liberdade de expressão, opinião e pensamento passou a ter novos contornos, de total proteção, garantindo novos matizes a esse direito em uma ordem democrática. Quanto à referida Lei 5250/67 esta sofreu uma sujeição a um procedimento no Supremo Tribunal Federal, tratou-se da Ação de Descumprimento de Preceito Fundamental (ADPF $n^{\circ}$ 130) ajuizada pelo Partido Democrático Trabalhista (PDT). Acatando o pedido formulado pelo PDT o STF declarou que a Lei de Imprensa não fora recepcionada pela Constituição Federal de 1988, o que acabou por suspender a aplicação da referida lei, conforme a decisão do plenário do STF em sessão realizada em 30 de abril de 2009.

Desta feita, a liberdade de expressão e os direitos a ela anexos e inerentes são iminentemente fundamentais para o bom funcionamento do regime democrático, de acordo com Dworkin (2006, p. 322) “[...] a liberdade de expressão é necessária para que o povo governe o governo e não vice-versa", assim no mesmo entendimento a liberdade de expressar os fatos e os conteúdos informativos é de caráter relevante a fim de montar os contornos sociais que serão possíveis a partir do que é veiculado, a liberdade de expressão não é importante porque as 
pessoas têm o direito moral intrínseco de dizer o que bem entenderem, mas porque a permissão para que elas o digam produzirá efeito benéficos para o conjunto da sociedade (DWORKIN, 2006, p. 318).

Com efeito, o ciberespaço codifica-se como sendo uma exponencial ferramenta para o exercício da liberdade de expressão hodiernamente, assim, “[...] percebe-se que as novas tecnologias da informação proporcionam uma alteração significativa na forma como ocorre a produção, distribuição e consumo das informações ${ }^{1}$ (OLIVEIRA, 2013, p. 333). Com isso, rompe-se com a tradicional comunicação unidirecional, característica da comunicação de massa, emergindo a possibilidade de uma interação plural que propicia uma diversidade de diálogos junto ao espaço público virtual (OLIVEIRA, 2013, p. 334), potencializando o palco da liberdade de expressão, a qual deve ser levado em consideração que "[...] a liberdade de expressão é em si mesma um elemento da justiça democrática (DWORKIN, 2006, p. 264). Em outras palavras, a liberdade de expressão constitui-se em um fim em si mesma, na medida em que "é, em si, um direito humano fundamental” (DWORKIN, 2005, p. 497).

Nessa esteira, vive-se um período de profundas e rápidas transformações no modo de comunicar e se informar, visto que os meios de comunicação tradicionais ou clássicos, como rádio, TV, periódicos e jornais acabam sendo “[...] transformados pelas novas formas de coletar, armazenar e transmitir informação" (DIZARD JR., 2000, p. 244), de modo que a Internet permite uma experiência ímpar ao aproximar emissor e receptor, se parte de uma mídia unidirecional, gerada e difundida por uma fonte centralizada e avança-se para uma nova mídia cada vez mais interativa, a qual permite que os consumidores possam escolher os recursos de informação desejados no momento e formato que quiserem (OLIVEIRA, 2013, p. 334).

Essas alterações na forma como a comunicação é exercida e como a informação é difundida a partir dos novos meios tecnológicos é mais que uma mera questão de transição do analógico para o digital, diz respeito a uma questão mais aprofundada, expõe elementos circunstanciais de poder na sociedade informacional contemporânea, dessa forma, o poder da informação confere àqueles que detêm as conexões da rede a possibilidade de influenciar os processos políticos e todas as demais interações sociais (OLIVEIRA, 2013, p. 335), na visão de Castells (2007, p. 572) as alterações no meio virtual das redes geram transformações nas relações de poder, acrescenta ainda que "[...] como a informação e a comunicação circulam

\footnotetext{
${ }^{1}$ Manuel Castells, todavia, alerta que "embora os meios de comunicação realmente tenham se interconectado em todo o globo, e os programas e mensagens circulem na rede global, não estamos vivendo em uma aldeia global, mas em domicílios sob medida, globalmente produzidos e localmente distribuídos" (2007, p. 426).
} 
basicamente pelo sistema de mídia diversificado, porém abrangente, a prática da política é crescente no espaço da mídia”.

Por sua vez, a Internet se consolida como uma nova mídia sem precedentes, ao associar os elementos mais atrativos presentes nos demais meios. Ela consegue se utilizar da velocidade na transmissão da notícia que o rádio apresenta, do entretenimento e das imagens atraentes com diversos recursos visuais que a TV propicia, tudo isso associado a novas técnicas de vídeo e animação, criadas especialmente para o mundo virtual (OLIVEIRA, 2013, p. 332), nos auspícios de Castells (2007, p. 82-89) “[...] a criação e o desenvolvimento da Internet nas três últimas décadas do século XX foram consequência de uma fusão singular de estratégia militar, grande cooperação científica, iniciativa tecnológica e inovação contracultural”.

A descentralização na produção dos conteúdos exasperados pelas novas mídias virtuais leva doutrinadores como Cardoso (2007, p. 120), a anunciar o surgimento de uma "nova democracia cultural", em que os lugares de produtor e consumidor, antes estabelecidos e fixos, são alterados, possibilitando que todos escrevam sobre tudo. Nessa esteira, partindo do pensamento de Silva (2013, p. 441) tal movimento revela-se interessante e saudável, eis que maximiza os canais para o exercício da liberdade de expressão. Na era digital "[...] o valor passa das mercadorias e dos imóveis para o controle da informação e outros bens intangíveis" (LIPTON, 2013, p. 442 apud SILVA), assim a informação adquire realidade própria, deixando de representar simplesmente a ideia, o conhecimento ou a opinião que se associa à qualidade de ser humano racional, para passar a ser considerada como um bem em si mesmo, imaterial sim, mas autônomo e anterior aos serviços de que constitui objeto.

Diferentes ramos da sociabilidade são fortemente impactados pelas tecnologias informacionais, as pessoas, atualmente ligam-se não apenas por meio dos computadores, mas também com telefones convencionais e celulares em franca expansão, desta feita, que serviços como governo eletrônico são instituídos, comunidades e redes sociais surgem com as ferramentas da Web 2.0, formas de ativismo político e protestos nascem, utilizam-se de tecnologias das mais diferentes redes informacionais (NASCIMENTO, 2013, p. 482), perfectibilizando a liberdade de expressão e novas formas de cultura, ou a partir dos novos meios técnicos e científicos e o intento digital a denominada cibercultura ${ }^{2}$. As consequências

\footnotetext{
${ }^{2}$ A cibercultura apresenta-se como um conjunto tecnocultural emergente no final do século 20, impulsionado pela sociabilidade pós-moderna em sinergia com a microinformática e o aparecimento das redes telemáticas mundiais. Ou, uma forma sociocultural que modifica hábitos sociais, práticas de consumo, ritmos de produção e difusão de informação, criando outras formas de relações de trabalho, lazer, sociabilidade e comunicação social. Esse
} 
desta se fazem presentes em todos os países do globo, e somente um pensamento global pode dar conta dos desafios da atual sociedade da comunicação e da informação planetária (LEMOS, 2010, p. 22).

Esse pensamento global é propício dessa nova roupagem tecnológica e social, e se dá em razão dos fluxos informacionais que os meios digitais hodiernos proporcionam, a economia global é hoje constituída pelas trocas e fluxos quase instantâneos de informação, capital e comunicação cultural. A sociedade permanece capitalista, mas a base dos meios tecnológicos com os quais ela age saltou da energia para a informação, assim a metáfora que caracteriza essa sociedade é a dos "espaços de fluxos", metáfora que caracteriza uma lógica organizacional independente de localização (SANTAELLA; LEMOS, 2010, p. 16), mas baseada em fluxos bidirecionais de informação e comunicação.

Barreto (1999) define fluxo de informação como a sequência de eventos de um processo que intermedia a geração de uma informação (fonte emissora) e a aceitação por parte do receptor. Na mesma linha de entendimento, Jamil (2001) trata o fluxo de informação como a transmissão de dados ou conjunto de dados através de unidades administrativas, organizações e profissionais, com o intuito de transmiti-las de um armazenamento para outro.

A contemporaneidade vivencia a transição entre um modelo de acesso restrito à informação para um modelo aberto e livre, no qual a informação se espalha por todas as superfícies e ambientes (SANTAELLA; LEMOS, 2010, p. 95), sendo assim a rápida transformação da cultura global dos fluxos indica uma reestruturação da arquitetura informacional da Internet em função dos laços sociais (ROSSITER, 2006), isto demonstra que a visualização dos laços sociais em fluxos de informação é fundamental para análise dos processos de mudanças provocados pelo ciberespaço.

Logo, em se tratando dos laços acima descritos, quando se refere a redes sociais, estes podem ser firmados a partir do acompanhamento das páginas e conteúdos de um determinado usuário, é a partir desse tipo de canal que pode se vislumbrar efetivamente um fluxo de informação. Dentro desse estágio, a percepção fulcral é a de que "[...] na era das mídias sociais, a ênfase não é mais na informação que nós buscamos, mas sim na informação que recebemos através das nossas conexões sociais" (SANTAELLA; LEMOS, 2010, p. 92), deste modo, segundo Rheingold (2010), as habilidades cognitivas da atenção são cruciais para saber

conjunto de novas informações e tecnologias comanda o ritmo das transformações sociais, econômicas, culturais e políticas do século 21 (NASCIMENTO, 2013, p. 483).

Rev. de Direito, Governança e Novas Tecnologias | e-ISSN: 2526-0049 | Porto Alegre | v. 4 | n. 2 | p. 22 - 43 | Jul/Dez. 2018 
gerenciar a complexidade dos fluxos informacionais, dentre elas destacam quatro essenciais, quais sejam: participação, colaboração, filtragem e presença consciente em rede.

Portanto e, com efeito, o uso das Tecnologias da Informação e Comunicação fomenta um lócus plúrimo para a exasperação das ideias, pensamentos, opiniões e juízos de valor, o ciberespaço funciona como uma ágora, ressonando os conteúdos nela difundidos, promovendo as multidimensionalidades da comunicação, onde a pluralidade de vozes e o exercício da liberdade de expressão formam o canal principal dessa nova morfologia social e dão o tom das novas matizes dessa organização calcada no poder da informação.

O ciberespaço e a utilização das tecnologias informacionais vem remodelando a forma de comunicação na contemporaneidade, na medida em que permitem ao usuário expressar sua opinião na rede e difundi-la, em uma estrutura baseada em fluxos de informação, os quais se traduzem em fluxos bidirecionais, onde há trocas intermitentes de conteúdos de informação, rompendo definitivamente com a unidirecionalidade que é a marca circunstancial da mídia hegemônica tradicional. Graças ao compartilhamento de informações ocorrido e potencializado pelos crescentes fluxos informacionais no ciberespaço, proporciona-se uma mudança, que diz respeito, sobretudo, a um novo olhar para fatos, notícias e informações, de modo a ampliar o espaço de crítica, reflexão e discussão acerca das mais diversas temáticas.

Nesse ínterim, a partir do poder baseado na informação, como um instrumento de remodelação das relações estabelecidas, e baseado também nas comunicações exercidas em larga escala a partir das TIC, o próximo eixo temático preocupa-se explanar, sobretudo a partir da difusão informativa e o impacto na agenda política. É sobre tal contexto que se passa a tratar.

\section{AUTOCOMUNICAÇÃO E CONTRAPODER NO CIBERESPAÇO: A UTILIZAÇÃO DAS TIC E O IMPACTO NA AGENDA POLÍTICA}

A comunicação é um valor de emancipação no âmago da cultura ocidental, expõe Wolton (2012, p. 36), esse pensamento do autor traduz a necessidade de trazer à baila o paradoxo da comunicação, o qual marcado pelos conceitos de liberdade, igualdade e fraternidade, valores essenciais da cultura política ocidental. Desde o século XVI a comunicação é o meandro e condição de todas as emancipações do indivíduo, e essa reivindicação da liberdade de comunicar é flagrantemente um fruto da batalha travada ainda no período da Renascença, pelas liberdades de consciência, de pensamento e de expressão. A partir dos séculos XVII e XVIII a busca se dá pela liberdade editorial e de imprensa, já no século

Rev. de Direito, Governança e Novas Tecnologias | e-ISSN: 2526-0049 | Porto Alegre | v. 4 | n. 2 | p. 22 - 43 | Jul/Dez. 2018 
XIX, a necessidade se refere à luta pelas liberdades de associação, de manifestação e participação política.

No século XX, o panorama modifica-se visto o surgimento da democracia de massa, o sufrágio universal e a informação disseminada a todos. Desta feita, os três séculos que precederam à democracia estiveram marcados pela luta quanto à liberdade individual, posteriormente pela igualdade, os quais são bandeiras indissociáveis da problemática que envolve a comunicação. Insta referir que não há sociedade aberta nem democrática sem liberdade de informação e de comunicação e as batalhas pela democracia, pela liberdade de imprensa, depois do rádio e da televisão, sempre tiveram sua ação inscrita nesta perspectiva de emancipação do homem (WOLTON, 2012, p. 36).

Dentro dessa perspectiva, a televisão, como meio de comunicação de massa aberto e gratuito, tem forte contingência no aparato disseminador e na performance de construção da consciência pública a partir dos fatos narrados e dos símbolos expostos, o espectador é o mesmo indivíduo que o cidadão, o que implica então terem as mesmas qualidades e defeitos. Caso acredite que o público da televisão é influenciável e manipulável, é preciso admitir que o cidadão também o seja. Nas palavras de Wolton (2012, p. 69) “[...] ora, a aposta da democracia é que, em detrimento das consideráveis desigualdades socioculturais, das prodigiosas diferenças nas aspirações coletivas e individuais, o cidadão pode ser a fonte da legitimidade democrática".

A importância desses meios de massa é tão grande política quanto socialmente, muito embora apenas o controle único desses meios, nas mãos do Estado, por exemplo, não garanta um pleito, visto que "[...] o controle das imagens não assegura o controle das mentes" (WOLTON, 2012, p. 70). Acerca do tema, o impacto das novas mídias e a implementação da cultura do digital na sociedade da informação, em que esta tornou-se fonte de poder e ingerência expõe as novas dinâmicas, operacionalizadas a partir dos fluxos informacionais e da Internet. A televisão, de uma forma mais ampla e massificada, também o rádio e a imprensa, dependem, diretamente, de uma lógica da oferta, já as novas mídias de uma lógica de demanda (WOLTON, 2012, p. 81).

Com a inserção das Tecnologias da Informação e Comunicação ${ }^{3}$, o cenário da comunicação massificada e unidirecional passou a modificar-se, “[...] as novas mídias passaram

\footnotetext{
${ }^{3}$ Considera-se que uma proposta de conceituação de TIC minimamente aceitável deve remeter ao conjunto de dispositivos, serviços e conhecimentos relacionados a uma determinada infraestrutura, composta por computadores, softwares, sistemas de redes etc., os quais teriam a capacidade de produzir, processar e distribuir
} 
a desempenhar uma força ainda mais importante para o desenvolvimento de uma consciência do papel da participação democrática e cidadã na vida social" (OLIVEIRA, 2013, p. 323), dessa forma, impactados pelas novas mídias informacionais ocorre à proliferação de novos espaços de exercício da cidadania em rede, o que permite a ampliação da participação social em assuntos de extrema relevância para o contexto social, cultural, político e econômico do país. O ciberespaço constituiu uma realidade para a prática da manifestação do pensamento, das ideias, dos juízos de valor e essencialmente da prática do direito à liberdade de expressão.

Dentro desse contexto, vale mencionar as palavras de Meyer-Pflug (2009, p. 209), para quem “[...] a liberdade de expressão é um direito individual que cada cidadão possui de expressar suas ideias sejam elas quais forem, sem sofrer qualquer restrição ou ameaça por parte do Estado ou sociedade". Esse arcabouço é uma forma de contemplar a possibilidade de expor os seus conteúdos e ideários sem receio ou temor, como preceitua a referida autora a liberdade de expressão “[...] consiste em um dos sustentáculos do Estado Democrático de Direito e abrange o direito ao discurso, direito de opinião, direito de imprensa, direito à informação e a proibição de censura".

Esse direito relaciona-se diretamente com a autodeterminação do sujeito, ao passo que ao receber influências do ambiente externo, cabe ao indivíduo escolher as ideias com as quais mais se identifica e discuti-las com os demais atores sociais, formando sua opinião (MEYERPFLUG, 2009, p. 68-69), e esse espectro se denota totalmente mobilizado a partir do intento tecnológico, visto que a articulação em rede propiciou a organização de discursos e a sistematização de ideias no ciberespaço.

Por conseguinte, "[...] a revolução da comunicação engloba tudo por onde passa, integrando cada vez mais serviços, abrindo possibilidades de interação em todas as direções" (WOLTON, 2012, p. 94), contudo algumas diferenças necessitam ser pontuadas quanto às novas tecnologias quem tem em sua base a Internet, e as estruturas informativas e comunicacionais anteriores. A primeira corresponde às funções, as novas mídias oferecem uma grande quantidade de informações de tipos e estatutos diferentes, quais sejam informaçõesserviços, financeiras, industriais, vez que a Internet é o império da informação disseminada e o paraíso da interação. Não há parâmetros de comparação com o que às mídias clássicas podem ofertar.

informações para organizações e sujeitos sociais. Um traço fundamental das TIC é o fato de serem produto da convergência e do imbricamento das telecomunicações com a informática e a computação (VELOSO, 2011, p. 49).

Rev. de Direito, Governança e Novas Tecnologias | e-ISSN: 2526-0049 | Porto Alegre | v. 4 | n. 2 | p. 22 - 43 | Jul/Dez. 2018 
A segunda diferença consiste na inserção social das novas tecnologias, vez que o mundo das mídias é tão estável quanto é instável o das novas tecnologias, instável do ponto de vista técnico, pois as performances estão cada vez mais ilimitadas, mas também do ponto de vista econômico, já que a guerra industrial transtorna terminantemente as relações de força em nível mundial. Por fim, a terceira e última diferença diz respeito aos meios profissionais e culturais. Se por um lado o mundo do rádio e da televisão logo se tornou prestigioso, ligado à política, à cultura, ao espetáculo, à imprensa, o mundo da informática, por sua vez, nunca conheceu tal notoriedade. As diferenças culturais entre os meios profissionais, as representações, o status, as tradições, são essenciais para compreender a atual situação de semiconcorrência entre esses meios (WOLTON, 2012, p. 96-97).

É inegável causado pelas novas dinâmicas propiciadas pelas tecnologias, antigas organizações como a política se vem confrontadas e desafiadas a apresentar uma nova formatação. Como menciona Gomes (2004, p. 42), fala-se em "especializações" do campo político em sua interação com a mídia. Conforme Lemos (2005, p. 02), a nova realidade trouxe uma importante contribuição para a modificação do processo comunicacional, antes regido pela lógica de emissor e receptor. Se, durante dois séculos, o ideal de informação foi de produzir e difundir o mais rápido possível uma informação, diretamente acessível ao público, sem intermediários que eram como censores, a realidade de hoje é sistematicamente inversa (WOLTON, 2012, p. 108).

A ligação e a programação exercida através da comunicação são formas de exercício de poder na sociedade em rede global, de modo que segundo Castells (2013, p. 92) "[...] resistirse à programação e interromper as ligações para defender valores e interesses alternativos são as formas de contrapoder que exercem os movimentos sociais e a sociedade civil - local nacional e global". Na sociedade em rede e informacional, os discursos geram, difundem e disseminam, incorporam a ação humana, no âmbito da comunicação globalizada, edificada a partir de redes locais-globais de comunicação digital, incluindo as mídias tradicionais ou clássicas e a Internet, visto que "o poder na sociedade em rede é o poder da comunicação" (CASTELLS, 2013, p. 93).

Dentro dessa perspectiva Castells (2013, p. 93) ainda aponta que na sociedade contemporânea, em todo o mundo, os meios de comunicação são a forma decisiva, onde a performance política através das mídias se reconfigura para uma nova forma de se fazer política através dos meios de comunicação. As mensagens, organizações, figuras e líderes que não têm presença midiática não existem para o público (CASTELLS, 2013, p. 267). 
Por conseguinte, somente àqueles que possuem presença midiática e que conseguem exasperar as suas mensagens aos cidadãos têm a possibilidade de influenciar as suas decisões de modo que os levem a posições de poder dentro do Estado ou a mante-se no centro de poder das instituições, o que corrobora a necessidade de controle sobre os meios de comunicação, edificando a concepção de que tal controle é uma eficiente forma de dominação (CASTELLS, 2013, p. 267). Insta estabelecer que de fato a política se desenvolve fundamentalmente nos meios de comunicação, embora isso não signifique que outros fatores não sejam importantes no momento de decidir os resultados das batalhas travadas nessa seara, bem como explicita Castells (2013, p. 268) "[...] tão pouco significa que os meios de comunicação ostentem o poder. Não são o quarto poder, são muito mais importantes, são o espaço onde se cria o poder".

Por sua vez, as TIC, tendo como estrutura de suporte único a Internet, compõem-se como grandioso instrumento de difusão informativa, impactando âmbitos de grande relevância, como e especialmente a seara política, alterando a composição e a agenda política sobre determinados assuntos, visto que as tecnologias informacionais tornam possível a articulação em rede dos movimentos e fazem, assim, ressoar as suas pautas e mobilizações. Aponta Castells (2003, p. 168) que "[...] o ciberespaço converteu-se numa ágora eletrônica global onde a diversidade do descontentamento humano explode numa cacofonia de pronúncias".

Muitos movimentos sociais, de diferentes bandeiras, matizes e espectros, a partir da década de 1990, tem encontrado na Internet uma forma de fazer ecoar as suas articulações e promover uma reação do ator político. A Internet converteu-se no componente indispensável aos movimentos sociais que eclodem na sociedade informacional, onde estes são movimentos destinados a tomar as mentes e não o poder do Estado (2003, p. 171). De um modo geral, esses movimentos usam da Internet como infraestrutura material para a sua organização, sem propósitos de apropriação dos poderes do Estado e sim como uma forma de também fazer-se protagonista dos acontecimentos públicos, influenciando os seus desdobramentos, contribuindo em sua expressão para o equilíbrio democrático, ou como propõe Castells (2003, p. 173) "[...] vencer o poder das grandes redes globais para assim reconstruir o mundo a partir de baixo".

Dentro dessa égide, Bonilla corrobora que a tecnologia deve ser vista como um elemento carregado de conteúdo, como representante de novas formas de pensar, sentir e agir que vem constituindo-se na sociedade contemporânea, o que desloca seu uso de uma racionalidade operativa para uma racionalidade complexa, aberta, polifônica. Logo, as novas mídias reivindicam a posse da verdade da informação contra os desvios da comunicação de massa, de 
modo que as TIC são os novos vetores de transformação infraestrutural na sociedade hodierna ${ }^{4}$. O seu princípio axial é a centralidade do conhecimento teórico como fonte de inovação e formação política, a sociedade se organiza em torno do controle social do conhecimento (SODRÉ, 2002, p. 21).

A este passo, a informação sempre foi um recurso básico para qualquer sociedade. A diferença está na maneira pela qual a informação é produzida, acessada e processada, o que significa que a discussão é mais abrangente e não se reduz a apologias e condenações (SODRÉ, 2002, p. 19). O acesso à Internet e às redes de serviços e recursos disponíveis pode constitui-se como uma das formas de democratizar as informações e ampliar o acesso dos sujeitos aos direitos sociais (VELOSO, 2011, p. 52), vez que a informação e a comunicação moldam a cultura e a cultura muda com o novo sistema de comunicação.

Os perfis de ampliação do exercício da cidadania no âmbito virtual cresceram exponencialmente nos últimos anos, dado ao incremento informacional e o aumento do acesso à Internet pelos indivíduos, de modo que, a manifestação de opiniões, juízos de valor e, consequentemente, o exercício do direito à liberdade de expressão, solidificou-se através dos blogs ${ }^{5}$ e redes sociais. A facilidade técnica propiciada com o surgimento dos weblogs ou blogs proporcionou um espaço de publicação de fácil manuseio, rompendo com os obstáculos da mídia de massa. Segundo Orihuela $(2007$, p. 2) "[...] blogs são páginas pessoais da web que, à semelhança de diários online tornaram possível a todos publicar na rede". Por isso, eles apresentam uma novidade formal, tendo em vista que a disposição do seu conteúdo foge do modelo tradicional baseado na hierarquização da informação de acordo com a sua importância para priorizar a informação mais recente (OLIVEIRA, 2013, p. 236).

No que tange a essa configuração, novos atores midiáticos se solidificam, expressando a fluidez e o caráter atemporal da informação disposto nos blogs. A esse aspecto, Oliveira (2013, p. 326) coloca. Logo, é flagrante o impacto da utilização das Tecnologias da Informação e Comunicação na arquitetura do ciberespaço, sobretudo no que diz respeito à agenda política

\footnotetext{
${ }^{4}$ Para que as potencialidades presentes no uso das TIC adquiram concretude, é necessário um sólido processo de apropriação deste recurso, marcado pela valorização de várias outras competências, e não apenas a tecnológica. A incorporação das TIC aos diversos processos e contextos sociais deve, para ser estratégica, viabilizar o avanço e o desenvolvimento pra o conjunto da sociedade, abordando dimensões tais como o avanço na luta pela defesa de direitos, pela ampliação e consolidação da cidadania, e pelo aprofundamento da democracia. Sem a garantia de tais pressupostos, o uso da tecnologia pode deixar de ser estratégico e cair na armadilha do tecnicismo (VELOSO, 2011, p. 47).

${ }^{5}$ A expressão "weblog" foi utilizada primeiramente por Jorn Barget, em 1997, para referir se a um conjunto de sites que "colecionavam" e divulgavam links interessantes na Web (AMARAL; RECUERO; MONTARDO, 2009, p. 28).
} 
e, especialmente, fomentando a constituição de observatórios da política e dos políticos, visto que uma amplitude de informações e notícias que não são veiculadas na mídia hegemônica comercial e privada pode ser facilmente encontrada nos blogs que compõem a blogosfera ${ }^{6}$, esses instrumentos funcionam como "[...] poderosos antídotos contra o jornalismo descuidado" (FOLETTO, 2009, p. 205).

Para Castells o poder da informação configura àqueles que detêm a articulação da informação em rede a possibilidade de influenciar os processos políticos na sociedade atual, para ele, "como a informação e a comunicação circulam basicamente pelo sistema de mídia diversificado, porém abrangente, a prática política é crescente no espaço da mídia" (CASTELLS, 2007, p. 572). A utilização eficiente das TIC é importante como ferramenta de debate, conscientização e fornece subsídio para a discussão de assuntos esquecidos ou deixados totalmente de lado pelas mídias clássicas, ou refutados quando contrários a seus interesses.

Conforme disciplina Oliveira (2013, p. 337) "[...] percebe-se que o avanço nas novas tecnologias informacionais gera um incremento na prática do ativismo, especialmente pela utilização das novas mídias. É na rede que muitos dos movimentos sociais passam a ter voz ativa e a se mostrar ao mundo", uma vez que "[...] a lógica e a organização da mídia eletrônica que enquadram e estruturam a política" (CASTELLS, 2006, p. 374). Um dos exemplos dessa ressonância pode ser descrita com a criação oficial do "Blog do Planalto", o qual fora criado pela Presidência da República, em 31 de agosto de 2009, com objetivo precípuo de servir como novo espaço de interação entre governo e sociedade. Entretanto a lógica adotada por essa ferramenta foi a da web 1.0, ou seja, marcada pela unidirecionalidade da informação, em que há apenas um fluxo informativo apenas do emissor para o receptor (OLIVEIRA, 2013, p. 338).

Rompendo com essa lógica, dando ênfase à arquitetura das TIC, após a criação do blog oficial, foi criado o "pseudo Blog do Planalto", uma página que tinha por missão replicar o conteúdo original do blog da Presidência da República, com diferencial que dá abertura aos cidadãos para se expressarem por meio de postagens, assim foi possível uma interação com os usuários, possibilitando comentar a partir de cada postagem realizada (lógica de web 2.0). Apesar os esforços compreendidos pelos criadores desse instrumento, o blog não se encontra mais em atividade, tendo suas últimas postagens realizadas no ano de 2012 (OLIVEIRA, 2013, p. 340).

\footnotetext{
${ }^{6}$ Blogosfera corresponde ao termo utilizado para definir o universo de Blogs presentes na Internet, que tem como objeto a difusão de informações, bem como a exasperação de críticas e opiniões.
} 
Embora hajam muitas pressões que exorbitam e circundam o meio comunicacional brasileiro - pressões de toda ordem: econômica, cultural, religiosa, política - e que influenciam na tomada de decisões também no meio virtual, como por exemplo, direta ou indiretamente a retirada do ar do "pseudo Blog do Planalto", muitos atores passaram a articular-se no ciberespaço, por meio da Internet, através de ferramentas como os blogs, redes sociais e páginas, possibilitando dar voz aos movimentos sociais, organizações da sociedade civil e também descortinando temas de relevância social que necessitam ser reverberados e discutidos. Logo, as tecnologias informacionais são primordiais nesse aspecto, dando abertura a vozes dissidentes, permitindo a mobilização e articulação em rede e permissionando o mais amplo exercício do direito à liberdade de expressão.

Nesse propósito que muitos setores organizados, ativistas, movimentos sociais específicos e também atores sociais tem se utilizado amplamente das tecnologias informacionais para que no ciberespaço possam começar a mobilizar-se em prol da reflexão, discussão e também da visualização de um tema específico, de uma causa ou demanda. Logo, a partir das TIC, um novo quadro passa a desenhar-se, pautado na interação e na mobilização por meio do espectro virtual, onde não há barreiras geográficas e temporais, podendo atingir-se uma amplitude de visualizações e com uma enorme gama de compartilhamento de informações e conteúdos.

\section{CONCLUSÃO}

Sociedade, tecnologia e informação constituíram os pilares do trabalho em tela, vez que consideraram-se os vieses da sociedade em rede, a qual segundo dispõe Manuel Castells tem o condão de a partir da utilização das novas tecnologias informacionais, determinantemente a Internet, revolucionar o contexto atual, possibilitando um amplo conhecimento, evolução e também auxiliando no processo que tem como cerne descortinar problemas, contextos e segmentos, alcançando uma maior interação entre os indivíduos sociais.

Nessa seara, conforme expõe Jean Lojkine se estaria diante de uma revolução informacional onde a informação se reveste em um prisma de fundamento exponencial, vez que possui o condão de transformar a sociedade e suas relações e, dentro desse contexto, que operou-se uma discussão essencial sobre os conceitos de contrapoder e autocomunicação, os quais confirmaram-se como novos e poderosos instrumentos possibilitados pela utilização da Internet e das novas mídias, vez que empoderam o indivíduo e cidadão frente às suas 
necessidades, fazendo-os, por exemplo, exercitar livremente o direito à liberdade de expressão, não necessitando de forma urgente e implicada as caixas de ressonância monopolizadas e homogêneas que consistem e subsistem os meios de comunicação de massa tradicionais.

Logo, em sede de apontamento conclusivo máximo verifica-se que as tecnologias informacionais, que possuem a Internet como suporte básico de desenvolvimento estruturam uma nova arquitetura comunicacional, já que atual como instrumentos de difusão informativa e necessariamente possuem um impacto na agenda política, especialmente as redes sociais, visto que a repercussão de certos temas, especialmente os socialmente sensíveis, tem a possibilidade profícua de reverberação no ambiente político nacional. Nesse contexto, que muitos blogs, plataformas digitais interativas e especialmente as redes sociais como Facebook ganham tamanha amplitude e penetrabilidade social e também política.

\section{REFERÊNCIAS}

ASCENÇÃO, José de Oliveira. Direito da Internet e da sociedade da Informação. Rio de Janeiro: Forense, 2002.

AMARAL, Adriana; RECUERO, Raquel; MONTARDO, Sandra Portella. Blogs: mapeando um objeto. In: AMARAL, Adriana; RECUERO, Raquel; MONTARDO, Sandra Portella (Orgs.). Blogs.com: estudos sobre blogs e Comunicação. São Paulo: Momento Editorial, 2009.

BARRETO, Aldo de Albuquerque. A Mudança estrutural no fluxo do conhecimento: a comunicação eletrônica. Ciência da Informação, Brasília, v.27, n.2, p. 122-127, mai./ago. 1999.

BAUMAN, Zygmunt. Medo líquido. Rio de Janeiro: Zahar, 2008.

BRASIL. Constituição da República Federativa do Brasil. Senado Federal.

Brasília, $1988 . \quad$ Disponível em: <http://www.planalto.gov.br/ccivil_03/Constituicao/Constituicao.htm>. Acesso em: 07 set. 2018.

CARDOSO, Gustavo. A Mídia na Sociedade em Rede: filtros, vitrines, notícias. Rio de Janeiro: Editora FGV, 2007.

A sociedade em rede - A Era da Informação: economia, sociedade e cultura. Tradução de Roneide Venâncio Majer. São Paulo: Paz e Terra, 2007.

CASTELLS, Manuel. A Galáxia da Internet: reflexões sobre a internet, negócios e a sociedade. Traduzido por Maria Luiza X. de A. Borges. Rio de Janeiro: Jorge Zahar, 2003.

A Era da Intercomunicação. Le Monde Diplomatique, agosto 2006. Disponível em: <http://www.diplomatique.org.br/acervo.php?id=1915>. Acesso em: 07 set. 2018. 
CAVALIERI, Sergio. Programa de responsabilidade civil. 9. ed. São Paulo: Atlas, 2010.

CGI.BR. TIC Domicílios indica que $31 \%$ da população brasileira usa Internet pelo telefone celular. Disponível em: <http://www.cgi.br/noticia/tic-domicilios-indica-que-31-dapopulacao-brasileira-usa-internet-pelo-telefone-celular/10044>. Acesso em: 07 set. 2018.

DIZARD JR., Wilson. A nova mídia: a comunicação de massa na era da informação. 2. ed. Tradução de Edmond Jorge. Rio de Janeiro: Jorge Zahar, 2000.

DWORKIN, Ronald. O direito da liberdade: a leitura moral da Constituição norte-americana. São Paulo: Martins Fontes, 2006.

Virtude soberana: a teoria e prática da igualdade. São Paulo: Martins Fontes, 2005.

FOLETTO, Leonardo. Blogosfera X Campo Jornalístico: aproximação e consequências. In: AMARAL, Adriana; RECUERO, Raquel; MONTARDO, Sandra Portella (Orgs.). Blogs.com: estudos sobre blogs e Comunicação. São Paulo: Momento Editorial, 2009.

GUILLEBAUD, Jean-Claude. O princípio da humanidade. São Paulo: Ideais\&Letras, 2008.

GOMES, Wilson. Transformações da Política na era da Comunicação de Massa. São Paulo: Paulus, 2004.

HISTÓRIA DO BRASIL.NET. Ditadura Militar no Brasil. Disponível em: <http://www.historiadobrasil.net/ditadura/>. Acesso em: 07 set. 2018.

JAMIL, G. L. Repensando a TI na empresa moderna. Rio de Janeiro: Axcel Books, 2001.

JENKINS, Henry. Cultura da Convergência. Tradução de Susana Alexandria. São Paulo: Aleph, 2008.

KAMINSKI, Omar. Aspectos jurídicos que envolvem a rede das redes. In: KAMINSKI, Omar (Org.). Internet legal: o direito na tecnologia da informação. Curitiba: Juruá, 2005.

LÉVY, Pierre. Cibercultura. Tradução de Carlos Irineu da Costa. São Paulo: Editora 34, 2009. Loyola, 1999.

A inteligência coletiva: por uma antropologia do ciberespaço. 2. ed. São Paulo:

LEMOS, André; LÉVY, Pierre. O futuro da Internet: em direção a uma ciberdemocracia. São Paulo: Paulus, 2010.

LEMOS, André. Ciber-Cultura-Remix. Artigo apresentado no seminário "Sentidos e Processos" dentro da mostra "Cinético Digital", 2005. Disponível em: <http://www.facom.ufba.br/ciberpesquisa/andrelemos/remix.pdf>. Acesso em: 07 set. 2018.

McLUHAN, Marshall. Undertanding Media. $2^{\mathrm{a}}$ ed. New York: New American Library, 1964.

MEYER-PFLUG, Samantha Ribeiro. Liberdade de expressão e discurso de ódio. São Paulo: Revista dos Tribunais, 2009.

NASCIMENTO, Valéria Ribas do. Constitucionalismo.com: O papel dos Estados entre "a transparência e a sombra" das novas tecnologias. . In. Direitos emergentes na sociedade 
global:anuário do programa de pós-graduação em direito da UFSM. Organizador Jerônimo Tybusch ... [et al.]. Ijuí, RS: Unijuí, 2013, (p. 473-501).

OLIVEIRA, Rafael Santos de. Dos Primórdios da Internet à Blogosfera: Implicações das mudanças nos fluxos informacionais na sociedade em rede. In. Direitos emergentes na sociedade global: anuário do programa de pós-graduação em direito da UFSM. Organizador JerônimoTybusch ... [et al.]. Ijuí, RS: Unijuí, 2013 (p.321-351).

ORIHUELA, José Luis. Blogs e blogosfera: o meio e a comunidade. In: ORDUÑA, Octavio I. Rojas et al. Blogs: revolucionando os meios de comunicação. Tradução VerticeTranslate. São Paulo: Thomson Learning, 2007.

RHEINGOLD, Howard. Attentionisthe fundamental literacy, 2010. Disponível em: <http://www.edge.org/q2010/q10_2.html>. Acesso em: 08 ago. 2018.

ROSSITER, Ned. Organized networks: media theory, creative labour, new institutions. Amsterdam: NAi Publishers, Rotterdam and the Institute of Network Cultures, 2006.

RHEINGOLD, Howard. Virtual communities - exchanging ideas through computer bulletin boards. In: Whole Earth Review, 1987. Disponívelem: <http://www.findasticles.com/p/articles/mi_m1510/is_n57/ai_6203867/pg_6>. Acesso em: 07 set. 2018 .

SALDANHA, Jânia Maria Lopes. Os Desafios do "Império Cibernético" na Era da Aceleração e da Informação: Um "sexto continente" de liberdade perfeita ou de controle perfeito? . In. Direitos emergentes na sociedade global: anuário do programa de pós-graduação em direito da UFSM. Organizador Jerônimo Tybusch ... [et al.]. Ijuí, RS: Unijuí, 2013, (p. 173-219).

SANTAELLA, Lúcia; LEMOS, Renata. Redes sociais digitais: a cognição conectiva do Twitter. São Paulo: Paulus, 2010.

SANTAELLA, Lúcia. Da Cultura das mídias à Cibercultura: o advento do pós-humano. In: Revista FAMECOS. Porto Alegre, $\mathrm{n}^{\circ}$ 22, dezembro. 2003. Disponível em: <http://www.revistas.univerciencia.org/index.php/famecos/article/viewFile/229/174>. Acesso em: 03 ago. 2018.

SANCHES BRAVO, Álvaro. A nova sociedade tecnológica: da inclusão ao controle social: a Europ@ é exemplo? Tradução de Clovis Gorczevski. Santa Cruz do Sul: EDUNISC, 2010.

SILVA, Jose Afonso da. Curso de direito constitucional positivo. 35. ed. São Paulo: Malheiros, 2012.

SILVA, Rosane Leal. A Proteção Integral dos Adolescentes internautas: limites e possibilidades em face dos riscos no ciberespaço. 2009. 515p. Tese (Doutorado em Direito), Universidade Federal de Santa Catarina. Florianópolis, 2009. Disponível em: $<$ https://repositorio.ufsc.br/bitstream/handle/123456789/93433/271103.pdf? sequence=1 >.

Acesso em: 28 mar. 2016.

SODRÉ, Munir. Antropológica do Espelho. Petrópolis, RJ: Vozes, 2002.

TAVARES, André Ramos. Curso de Direito Constitucional. São Paulo: Saraiva, 2002.

Rev. de Direito, Governança e Novas Tecnologias | e-ISSN: 2526-0049 | Porto Alegre | v. 4 | n. 2 | p. 22 - 43 | Jul/Dez. 2018 
VELOSO, Renato. Tecnologias da Informação e Comunicação: desafios e perspectivas. São Paulo: Saraiva, 2011. 